\title{
Gender Differences in Preference of the Wage Level and Risk on the Czech Labour Market
}

\author{
Dagmar Brozova \\ Dominik Stroukal \\ University of Economics Prague, Czech Republic ${ }^{3}$
}

Doi: 10.19044/esj.2018.v14n4p73 $\underline{\text { URL:http://dx.doi.org/10.19044/esj.2018.v14n4p73 }}$

\begin{abstract}
This work focuses on the preference theory and shows that this theory is valid also in the Czech labour market. In this paper, we posed three hypotheses, which we verified using four models with 2011 data about 1984 Czech employees. The first hypothesis says that women will prefer intrinsic rewards compared to high wages more likely than men. This hypothesis was verified. It turns out that women prefer higher wages against other nonmonetary job characteristics with $6 \%$ lower probability. The second hypothesis that women with a university education will prefer intrinsic rewards with the same probability as men the same degree was also verified. Czech data, however, shows that university education is associated with $40 \%$ higher preferences of intrinsic rewards, which is inconsistent with previous findings. Thirdly, it was shown that women prefer less risk than men, by 0.7 points on a scale of $0-10$, while gender does not matter among people with university education.
\end{abstract}

Keywords: Gender economics, preference theory, risk preferences, wage preferences

\section{Introduction}

The tendency of men and women to choose different occupations and job positions on the labour market is an important information for employers and has a number of implications for the labour market, the whole society and individual candidates. There are industries and jobs sought more by men than women and vice versa, and this is one of the causes of the difference in earnings between men and women (O'Connell \& Betz, 1996, Hakim 2000, Blau \& Kahn, 2007). According to Daymont and Andrisani (1984), this

3 This article uses anonymized data from research for the project of the Czech Science Foundation, No. GAP402/11/2462. The opinions and findings presented in this paper are exclusively of the authors. 
explains, for example, from one to two thirds of the earnings differential. This gender segregation is the subject of an intensive research, oriented among others on identifying the causes of different gender choices on the labour market, both on the demand side and the supply side.

This paper aims to determine preferences regarding job descriptions for data from the Czech labour market. It examines whether there are differences in preferences of the salary, non-financial nature of the job and the risk between the Czech men and women.

The deciding about hiring labour is influenced by the decisions of employers about whom to hire for appropriate jobs. They are governed, besides the quality of candidates, both general and personal experience. Some authors in this regard indicate that women often have to face societal and employers' stereotypes, therefore, the general habit of hiring men exclusively for certain positions. Employers thus build a barrier to women's access to certain job positions, and often even those most influential in the organization, which can result in slower advance in their career, or the in inability to achieve certain job positions (the glass ceiling) (Huffman et al., 2010 ). Others write about trying to preserve the "privilege" of men to occupy certain positions (Blau \& Kahn, 2000).

Gender segregation may also come from the supply side of the market. Women and men make different decisions about their choice of job. Research in this line agree that men and women make different choices already in the selection of the field of education and it then establishes their different preferences in choosing a job; women aspire for some jobs much less than men (Daymont \& Andrisani 1984, Becker, 1985 a 1997, Hull \& Nelson, 2000, England and Li, 2006).

Why men and women choose different jobs and make different career decisions? This is also explained by the individual preferences of the particular characteristics of the job position. A man prefers a job with characteristics that he or she values individually at most; be it the wage rate, intellectual challenge, or social prestige. There is a rich literature that argues that these preferred characteristics for men and women differ, therefore, that men and women seek jobs with different characteristics. This article will focus specifically on those preferences on the Czech labour market.

\section{Theoretical background: a Literature Review}

As far as preferences for specific characteristics of the job position are concerned, the literature is essentially based on traditional family roles, where the man is the one who provides for the family financially, is the primarily earning person, while a woman is possibly a secondarily earning person, because she takes a greater share of responsibility for the functioning of the household and childcare (Hakim, 2000). To that end, women spend a 
considerable portion of their forces, and therefore tend to be willing and prepared to perform less effort on the labour market than men (Bielby \& Bielby, 1988). It then influences different requirements and expectations of the job position, since women count on the fact that the duration of their participation in the labour market will be shorter than men, and therefore their investment in human capital may be lower (Becker, 1964). Already selecting the field of university studies, the men and women prepare for different industries and jobs in the labour market. Generally speaking, men more than women choose e.g. to study mathematics, IT, business, finance, engineering, women prefer disciplines of humanities, health, education. Despite the growing number of women in non-traditional fields for them, the differences persist (Polachek, 1978, Miles, 2013). The validity of the theory of preferences for the Czech Republic was verified by Brožová and Stroukal (2015).

Daymont and Andrisani (1984) tested the importance of the four characteristics of job position and career: the opportunity to earn money, the opportunity to be a leader, an opportunity to help others and the opportunity to work with people. It turned out that these attributes unanimously identify differences in the preferences of men and women. Men more than women felt the opportunity to earn money as a very important aspect for job and career choice. Men are assertive and dominant, more than women, and more than women felt the importance of choosing a job or career that offers the opportunity to be a leader. On the other hand, women more often than men marked important to be able to help others or society and appreciated the opportunity to work with the right people. Male preference for making money or for the opportunity to be a leader increases the likelihood of search positions in business, finance, IT, while traditional female preference helping others or working with people creates the opposite effect: preference for humanities, health, education.

Betz and O'Connell (1989) also report that when choosing a job, men more than women consider the level of income, job security and career possibilities, while women emphasize the opportunities to use special abilities or to work with people. The traditional division of labour in the family leads women to award less time-consuming work, because women feel more pressure to reconcile work and family life than men (Meneghan 1991, Moen, 1992). If a woman in connection with these preferences chooses certain types of employment that are at a disadvantage on the labour market, it is not a consequence of any restriction or even discrimination, but of their own choice (O'Connell \& Betz, 1996). The finding by Marini et al. (1996), that women assessed the money as less important characteristic of a job than men, is in accordance. 
Konrad et al. (2005) come with a slightly different point of view and different findings. They focused their attention solely on students of MBA programme (they examined a sample of 171 men and women). All of them, men and women, were led to entry into the programme by their common preference for high wages and good employment opportunities for careers. The authors investigated whether family responsibilities limit career, and more so for women than for men. Here is the original expectation not confirmed; data showed that family responsibilities does not have a significant effect on the result of career for men and women. The presence of a partner, eventually children, and the need for a certain number of hours of housework had no significant impact on career outcomes. But the authors themselves state that their respondents were followed only three years after joining the programme. They do not rule out that the impact on their career may occur later.

Already earlier Konrad et al. (2000a) conducted a meta-analysis of 242 studies elaborated between the years 1970-1998 in the US, and revealed significant gender differences in 33 out of 40 preferential characteristics regarding job positions and careers. In a similar study (Konrad et al., 2000b) specifically aimed at managers (meta-analysis of 31 studies), they found differences, but not significant between the preferences of men and women, in 9 out of 21 investigated characteristics of the job position. Another 12 gender differences showed significant. According to them, e.g. men considered earnings and accountability as more important characteristics of work than women, while women consider job security, social prestige of the job, new challenges, the importance of the task, the variety of work, safety of work, good colleagues and good leadership, and comfortable working environment for more important characteristics of work than men. Especially the prestige of work and new challenges are characteristics that are, according to the authors of the study, more consistent with masculine rather than feminine ideology. And so the fact that women consider the challenges and prestige as more important features than men, contradicts, according to the authors, the expected gender roles. The authors formulate conclusions that e.g. the fact that men ascribe great importance to earnings and accountability implies that they seek higher wages more than women. The finding that women give more importance to security of the work and comfortable environment, means that they are willing to exchange earnings for non-monetary aspects of the job. One should not forget that the observed differences were small. The authors state that greater differences discovered were discovered within each sex than between them (Konrad et al. 2000a, p. 126).

The next chapter will formulate three hypotheses for the verification of which we will set four models in the second chapter. In the third chapter we will present data and in the last chapter results of the estimated models including discussion. 


\section{The Hypotheses}

Tolbert and Moen (1998) hypothesized that men are more likely than women to consider a high income and opportunities for professional advancement as a top workplace characteristics. On the contrary, women are more likely than men to consider as the preferred characteristics of the job description and shorter working hours. Their data showed that gender differences regarding preferences regarding the characteristics of the job position for married women and married men employed full-time were relatively small. Nevertheless, they could indicate gender significant predictor of preference, on the base of their research, for the three characteristics of the job: meaningful work, opportunities for professional advancement and job security. Women more likely than men preferred to work with meaningful content and greater confidence and were less likely to give priority to career possibilities. The authors concede that such preferences can lead women to choose such jobs, which are paid less, and thus contribute to the gender wage differences. At the same time, the authors have identified education as a further significant preferences predictor. People with higher levels of education gave more priority to high income and opportunities for advancement. The authors state that white-collar workers are more often identified with high incomes, while the blue prioritise job security.

At the same time, the research by Tolbert and Moen did not confirm that the different preferences of men and women would no converging over time, it rather suggest that they will persist. These findings are consistent with many previous studies that have reached essentially the same findings - the fact that men more than women prefer extrinsic rewards, while women prefer intrinsic rewards (Tolbert \& Moen, 1998; Miles, 2013).

Data by Barbulescu and Bidwell (2013) also confirmed the hypothesis that women prefer a position with anticipated positive attitude towards worklife balance. It covered the positions in general management, which were preferred by women for finance and consulting where the path to reconciling work and family life is harder. Further, the researchers confirmed that women were less likely to identify with a position that is generally perceived as masculine, while women are less likely than men to expect that they would be given an offer of such a position and they are also less likely to expect the success, namely that they could actually get such a position.

Miles (2013) in the research wondered why educated and successful women leave the job. From the statistics, it had shown that the examined 10year period (US Census Bureau, 2003), the women left jobs five times more frequently than men. And it confirmed the hypothesis that the reason was the impossibility of reconciling the responsibility for work and home. 
In this paper we formulate four hypotheses. Our first hypothesis is based on the above stated facts and will cover the preferences about the level of the salary.

\section{H1: Women are less likely than men to prefer positions with high salary.}

Other findings were brought by research conducted by Barbulescu and Bidwell (2013). They examined the factors according to which the equally qualified men and women choose their job position. They chose a homogeneous group of MBA programme graduates, which were prepared for well-paid and influential positions in general management, finance and consulting, which are traditionally the domain of men. They found that all graduates of the MBA programme applied for well-paid jobs, respectively the relationship between gender and salary levels was not significant. Their research did not confirm the hypothesis that women are less likely than men to choose positions with high salary. Students of these programmes are ambitious, investing heavily in their careers and are looking for a position at a high level of pay and prestige, without distinction of gender. Similar conclusions were reached also by O'Neill and O'Reilly (2010) in their study.

Because we consider this as an interesting finding, we are going to test similarly the data from out dataset, we will therefore assume that

H2: University (and higher) education increases the preference for positions with high salary. Women and men with university (and higher) education prefer a position with a high salary with equal probability.

Croson and Gneezy (2009) identified a robust gender differences in three areas: the preference for risk (risk preferences), social preferences (social preferences), and preferences regarding competition (competitive preferences). By the method of economic experiments, they confirmed their hypothesis that women are more risk-averse than men. This conclusion is consistent within numerous other studies that examine the relationship of women to risk in different situations and different methods. Croson and Gneezy further precise their conclusions that unmarried women are more risk averse than unmarried men and women generally invest more conservatively than men. The explanation is seen in different emotional reactions to risky situations in which women show a greater intensity of nervousness in anticipation of a negative outcome than men. This causes low utility of risk alternatives and establishes a different relationship to the risk for women as opposed to men. Men understand the risk situation as a challenge, they are more self-confident, and it leads to a greater risk tolerance.

Surveys that focus only on selected groups of workers, however, are running again to different conclusions. Atkinson, Baird and Frye (2003) compared the investment behaviour of managers and entrepreneurs. They 
found that the risk preferences regarding gender did not significantly differ; differences were associated with investment knowledge and the extent of property. Johnson and Powell (1994) have reported similar conclusion. They examined the decision-making characteristic of men and women in management (with formal management education and managerial management position) and non-management population (without formal management education and without managerial positions). In the group of managers, men and women showed the same willingness to take risks and make decisions the same quality, but in the non-management group, the women were more risk-averse than men. The authors interpret these results as a result of free choice of jobs. People, who prefer more risk than others, choose managerial positions because they are ready to face the risk. Just when women choose this position, then they have a similar relationship to risk as men in these positions and make similar decisions.

It can be assumed that this gap will exist also between employees. Therefore, our third hypothesis will be

\section{H3: Women are more risk averse than men and have lower preferences for the competitive situation than men Models}

To validate our first hypothesis, we use the method of Probit, when we estimate the probability that the respondent prefers intrinsic rewards depending on a number of variables. The first and most important is the zerounit variable Woman which takes the value 1 for women and 0 for men. By cleaning the estimate from three variables recording the respondent's education and seven other variables with personality and work performance characteristics we obtain, for the variable Woman, the estimation of the impact of gender itself on the preference intrinsic rewards, and we expect that this impact will be positive.

To verify the first hypothesis, we compiled, on the basis of the above, the following model:

$P\left(\right.$ Intrinsic $\left._{i}=1 \mid x\right)=\beta_{0}+\beta_{1}$ Woman $_{i}+\beta_{2}$ Secondary education $d_{i}+\beta 3$ Secondary education with school diploma ${ }_{i}+\beta 4$ University education

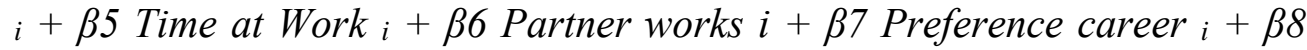
Pride $i+\beta 9$ Request to increase $i+\beta 10 \log$ (Income) $_{i}+\beta 11$ Individual approach $_{i}+u_{i}$

In this model, we expect due to the hypothesis that the coefficient $\beta_{1}$ assume positive and significant value, therefore that women prefer more intrinsic rewards than men.

To test the second hypothesis, we added to the first model, two more variables capturing the combined effect of gender and graduating from 
university, so Woman university and Man university. We estimate Model 2 in the form:

$P\left(\right.$ Intrinsic $\left._{i}=1 \mid x\right)=\beta_{0}+\beta_{1}$ Woman $_{i}+\beta_{2}$ Secondary education $_{i}$ $+\beta 3$ Secondary education with school diploma ${ }_{i}+\beta 4$ Time at Work $_{i}+\beta 5$ Partner works $i+\beta 6$ Preference career $_{i}+\beta 7$ Pride $_{i}+\beta 8$ Request to increase ${ }_{i}+\beta 9 \log$ (Income) $_{i}+\beta 10$ Individual approach $_{i}+\beta 11$ Woman university $_{i}$ $+\beta 12$ Man university $i+u_{i}$

In this model, we will consider the second hypothesis as proven if the sum of the coefficients $\beta_{1}+\beta_{11}$ is negative and will take the same values as the coefficient $\beta$ 12. In other words, we confirm the hypothesis, if on the one hand, university-educated women prefer less intrinsic rewards through their education and also men, while for university educated people it does not depend on gender. So if the first hypothesis is correct, the preference penalty of intrinsic rewards for university education for women is higher than the bonus to their preference for the sex itself, i.e. $\beta_{1}<-\beta_{3}$

To verify the third hypothesis, we use the least squares method. The explained variable is the amount of risk accepted, which is expressed on a scale of 1 to 10 where 1 is no risk at all and 10 is very high risk. Model 3 will therefore be estimated in the form:

The risk level $=\beta_{0}+\beta_{1}$ Woman $_{i}+\beta_{2}$ Secondary education with school diploma $_{i}+\beta 3$ University education ${ }_{i}+\beta 4$ Partner works $_{i}+\beta 5$ Preference career $_{i}+\beta 6$ Pride $_{i}+\beta 7$ Request to increase $_{i}+\beta 8 \log$ (Income) $i+\beta 9$ individual approach $i+\beta 10$ Age $25-34+\beta 11$ Partner $+u_{i}$

Due to the hypothesis tested, we expect that women will prefer less risk, therefore, that the coefficient $\beta_{1}$ is significant and negative.

Finally, we estimate a model 4 , where we add again to the model 3 variables capturing the combined effect of gender and higher education. Model 4 will be estimated in the form:

The risk level $=\beta_{0}+\beta_{1}$ Woman $_{i}+\beta 2$ Secondary education with school diploma $_{i}+\beta 3$ Partner works $i+\beta 4$ Preference career $_{i}+\beta 5$ Pride $_{i}$ $+\beta 6$ Request to increase ${ }_{i}+\beta 7 \log$ (Income) $_{i}+\beta 8$ Individual approach $_{i}+$ $\beta 9$ Age 25-34 + Partner $\beta 10+\beta 11$ Woman with university ${ }_{i}+\beta 12$ Man with university+ $u_{i}$

\section{Data}

Data for this research include 1984 observations when a Czech employee aged from 25 to 54 years, working actively during survey, was elected as the observed unit. Data come from a questionnaire survey from the project of the Czech Science Foundation, No. GAP402/ 11/2464 Measurement of wage discrimination by gender in 2011 in the Czech Republic. 
The crucial variable for the verification of our hypotheses is a new variable Intrinsic created from our data. It was defined as Intrinsic $=1$ if the respondent answered most questions concerning precisely these values positively. For each question, the respondent had a choice of four answers (yes, rather yes, rather no, no), while we consider as positive both yes and rather yes. These questions were five, therefore, we consider that an affirmative answer at least three in cases, the respondent prefers intrinsic rewards. The five given questions are asked about preference for job security, flexibility of employment (opportunity to work at home, to work part-time, flexible hours, etc.), the possibility of self-fulfilment in employment, lower stress, and good interpersonal relationships in the workplace, always compared with the amount of wage. Intrinsic finally takes positive values in nearly 37 percent of cases. Even from a simple comparison, it can be seen that the intrinsic rewards are given higher preference by women (44\%) than by men $(31 \%)$. For a more detailed verification, however, it will be useful to clean impact on preference for remunerations from other influences, which may differ for men and women.

Another important variable is the Level of risk. It is built on a scale of 0-10 based on the question: "How high is the risk you are ready to carry in your working career? Mark your position on the following scale from 0 (no risk) to 10 (very high risk). " This variable was for several models transformed into the form of zero-unit variables, where, however, showed a range of economic and econometric problems, therefore, it remain used in this work as variable with values of $0-10$, while the frequency division was tested positive as normal. Already from the dataset overview, it is apparent that the amount of risk accepted by women is lower than by men. Although the average of respondents is 5 , for women it is about 4 and in for men approximately 6 .

In addition to these variables, we use a number of variables capturing the personal and professional characteristics, such as gender (woman $=1$ for women), education, income, age, relationship, etc.

Overview dataset is recorded in Table 1.

Table 1 - Dataset overview (\%)

\begin{tabular}{|c|c|c|c|}
\hline Characteristic & Population & Women & Men \\
\hline Intrinsic rewards & 37 & 44 & 31 \\
\hline Risk level (0-10) & 5 & 4 & 6 \\
\hline Primary education & 4 & 4 & 4 \\
\hline Secondary education & 74 & 71 & 76 \\
\hline University education & 21 & 24 & 20 \\
\hline Number of hours at work & 42 & 40 & 43 \\
\hline Partner works & 60 & 67 & 53 \\
\hline Preference career & 29 & 22 & 36 \\
\hline Pride & 76 & 76 & 77 \\
\hline Request for salary increase & 50 & 42 & 57 \\
\hline Income (CZK) & 20196 & 17550 & 22559 \\
\hline Individual approach & 46 & 46 & 47 \\
\hline
\end{tabular}




\begin{tabular}{|c|c|c|c|}
\hline Partner & 71 & 71 & 71 \\
\hline Age (years) & 39 & 39 & 39 \\
\hline One or more children & 67 & 72 & 62 \\
\hline Feeling of discrimination & 8 & 13 & 4 \\
\hline Great city & 23 & 24 & 22 \\
\hline
\end{tabular}

$\mathrm{n}=1984,936,1048$

\section{Results and Discussion}

The results of estimation of the above presented models are summarized in Table 2:

Table 2 - Result of models

\begin{tabular}{|c|c|c|c|c|}
\hline $\begin{array}{l}\text { Explained } \\
\text { variable }\end{array}$ & $\begin{array}{l}\text { Intrinsic } \\
\text { rewards }\end{array}$ & & Level of risk & \\
\hline $\begin{array}{l}\text { Explanatory } \\
\text { variable }\end{array}$ & $\begin{array}{c}\text { Model } 1 \\
\text { Probit } \\
\text { Marginal effects }\end{array}$ & $\begin{array}{c}\text { Model } 2 \\
\text { Probit } \\
\text { Marginal effects }\end{array}$ & $\begin{array}{l}\text { Model } 3 \\
\text { OLS }\end{array}$ & $\begin{array}{l}\text { Model } 4 \\
\text { OLS }\end{array}$ \\
\hline Constant & $\begin{array}{c}2,674+++ \\
(0,929)\end{array}$ & $\begin{array}{c}2,726+++ \\
(0,931)\end{array}$ & $-3,517++$ & $\begin{array}{c}-3,463++ \\
(1,548)\end{array}$ \\
\hline Woman & $0,056++$ & $0,044++$ & $\begin{array}{c}-0,660+++ \\
(0,111)\end{array}$ & $\begin{array}{c}-0,692++ \\
(0,123)\end{array}$ \\
\hline $\begin{array}{l}\text { Secondary } \\
\text { education }\end{array}$ & $0,136++$ & $0,135++$ & & \\
\hline School diploma & $0,262+++$ & $0,263+++$ & $\begin{array}{c}0,351+++ \\
(0,116)\end{array}$ & $\begin{array}{c}0,355+++ \\
(0,117)\end{array}$ \\
\hline $\begin{array}{l}\text { University } \\
\text { education }\end{array}$ & $0,372+++$ & & $\begin{array}{c}0,430+++ \\
(0,145)\end{array}$ & \\
\hline Time at work & $-0,003+$ & $-0,003+$ & & \\
\hline Partner works & $0,053++$ & $0,053++$ & $\begin{array}{c}-0,427+++ \\
(0,163)\end{array}$ & $\begin{array}{c}-0,430+++ \\
(0,163)\end{array}$ \\
\hline Preference career & $-0,079+++$ & $-0,079+++$ & $\begin{array}{c}0,406+++ \\
(0,110)\end{array}$ & $\begin{array}{c}0,407+++ \\
(0,110)\end{array}$ \\
\hline Pride & $0,045+$ & $0,044+$ & $\begin{array}{c}0,324+++ \\
(0,118)\end{array}$ & $\begin{array}{c}0,322+++ \\
0,118)\end{array}$ \\
\hline $\begin{array}{c}\text { Request for salary } \\
\text { increase }\end{array}$ & $-0,084+++$ & $-0,085+++$ & $0,645+++$ & $0,644+++$ \\
\hline Income (log) & $-0,130+++$ & $-0,131+++$ & $\begin{array}{c}0,764+++ \\
(0,158)\end{array}$ & $\begin{array}{c}0,760+++ \\
(0,158)\end{array}$ \\
\hline $\begin{array}{l}\text { Individual } \\
\text { approach }\end{array}$ & $0,124+++$ & $0,126+++$ & $\begin{array}{c}0,297+++ \\
(0,102)\end{array}$ & $\begin{array}{c}0,300+++ \\
(0,103)\end{array}$ \\
\hline Age 25-34 & & & $\begin{array}{c}0,251++ \\
(0,106)\end{array}$ & $\begin{array}{c}0,248++ \\
(0,106)\end{array}$ \\
\hline Partner & & & $\begin{array}{c}0,396++ \\
(0,175)\end{array}$ & $\begin{array}{c}0,399++ \\
(0,175)\end{array}$ \\
\hline $\begin{array}{c}\text { Woman university- } \\
\text { educated }\end{array}$ & & $0,349+++$ & & $\begin{array}{c}0,500+++ \\
(0,189) \\
\end{array}$ \\
\hline $\begin{array}{l}\text { Men university- } \\
\text { educated }\end{array}$ & & $0,396+++$ & & $\begin{array}{l}0,362+ \\
(0,187)\end{array}$ \\
\hline $\operatorname{Adj}^{2}$ & 0,120 & 0,121 & 0,123 & 0,123 \\
\hline
\end{tabular}

$\mathrm{n}=1984, \operatorname{AdjR}^{2}$ is adjusted coefficient of determination

standard error of constant is given in brackets

,,++++++ , the significance of the estimation at $1 \%, 5 \%$, and $10 \%$ level of signifikance 
Model 1 was estimated to verify the first hypothesis about the intrinsic rewards preference for women. It shows that for women, the intrinsic rewards preferences are actually more important than for men, and the difference is about $6 \%$. The estimation is significant and model 1 correctly predicts $65,7 \%$ of cases. The model was also tested positively for the normality of residues and negatively for the unbearable collinearity. Hypothesis 1 is therefore confirmed - women prefer less likely than men the positions with higher salary. So, the hypothesis formulated by Tolbert and Moen (1998) and verified a number of following authors, was confirmed.

At this point, we cannot finally answer the question, what causes this difference between men and women. Gender studies formulated a number of hypotheses of social and cultural determination of different views, for the purposes of our economic examination, however, we limit ourselves to saying that this distinction clearly exists.

The fact known from studies of gender wage gap, that a simple comparison of the differences between men and women provides greater value than that displayed by a more complex estimation cleaned from other factors, turns out. When a simple comparison reveals that the intrinsic rewards are preferred by women in $44 \%$ and by men and $31 \%$ of cases, i.e. they are are more preferred by women by $42 \%$ (13 percentage points). After cleaning from a range of influences, this difference falls down about $6 \%$.

The reverse causality is excluded in these models to explain the influence of sex as it does not make sense that preference intrinsic rewards determined the sex of the respondents.

Among other variables, it is interesting, and against our expectations that with higher education the preference intrinsic rewards is growing. Compared to respondents with primary education, it is $14 \%$ more with secondary education, $26 \%$ more with secondary school with diploma, and with university graduates and even by $37 \%$. There we can assume the relationship when higher education leads to a preference for intrinsic rewards while their preferences lead to higher education, since these respondents have lower opportunity cost of their studies.

Higher salary compared to non-financial rewards is preferred by those who work more hours per week, respondents who prefer career for family, those who asked for a raise of and, not surprisingly, also respondents with higher income.

Conversely, intrinsic rewards versus higher salary is connected in addition to the aforementioned education to the pride of respondents, to the work with an individual approach and also whether the partner of the respondent is working. If the partner works, people rather prefer intrinsic rewards, more than 5\% compared to respondents without a partner or with a partner who does not work. The influence of children nor their number, age 
of respondents, either the region or municipality size, was not confirmed. All these variables were insignificant in various estimates.

It is interesting that even within the various intrinsic rewards, there are differences between men and women, as shown in Table 3, and that in all categories examined women prefer a salary less than men.

Table 3 - Preference intrinsic reward (\%)

\begin{tabular}{|c|c|c|c|}
\hline Intrinsic vs. & Population & Women & Men \\
\hline Job security & 75 & 80 & 69 \\
\hline Flexibility & 20 & 23 & 18 \\
\hline Fulfilment & 28 & 30 & 26 \\
\hline Lower stress & 33 & 39 & 27 \\
\hline $\begin{array}{c}\text { Interpersonal } \\
\text { relations }\end{array}$ & 53 & 61 & 47 \\
\hline
\end{tabular}

$\mathrm{n}=1984,936,1048$

Model 2 has been expanded in comparison to the previous one with two combined variables capturing the influence of university studies for men and women. The model correctly predicts $66 \%$ of cases and residuals are normally distributed, and again in the model is no unsustainable colinearity present. Estimation of variables is almost identical to the previous model, with the exception of sex and higher education.

The estimation for the variable sex (woman) is now at $4 \%$, but sex is reflected in the combined variable (Woman with universities). Women without university then differ from the men without university differs by $4 \%$. Bonus of intrinsic rewards preference for women with university education is $35 \%+4 \%$ for gender, for men $40 \%$, both estimates are significant. The numbers $40 \%$ for men and $39 \%$ for women are due to the amount of standard deviations regarded as similar numbers.

The second hypothesis is rebutted for the Czech Republic, although its part remains valid. It is true that among university-educated respondents there is no difference in gender in the preference intrinsic rewards. Men and women with a university prefer the level of salary and non-financial rewards with the same probability, while for respondents without university education, there is a higher preference for salary for men. The second part of the hypothesis is not confirmed. Respondents with university education prefer intrinsic rewards more, and even by $40 \%$.

For a better test of this hypothesis, it would be appropriate to monitor the respondents in time and see what is the effect of university to respondents who had not previously have a university degree and earned it later. The problem would be that the plan for university education can occur several years before the study, then it would be necessary to monitor the change only for students who graduated from university, although before did not want to, which we consider methodologically very problematic. 
Models 3 and 4 were assembled for verification of the third hypothesis and to complement the previous two. From the estimation of the model 3 it is seen that women actually prefer lower risk by an average of approximately 0.7 points on a scale from 0-10. Again, it shows that compared to the aforementioned simple estimation of data, where women prefer the risk by 2 points less compared to men, the cleaned and more accurate estimation of this difference is reduced to less than half. Nevertheless, our third hypothesis is confirmed.

In the original model, the impact of university education was positive 0.4 point. When estimating variables combining gender and higher education, it is shown that women with lower than a university education prefer the risk by 0.7 percentage points less than men with equivalent education and other characteristics, but women with a university compared to these men prefer risk only 0,2 points less. In comparison with university educated men, the university educated women prefer the risk by 0.6 percentage points less. Bonus for university at the risk preference for women is 0.1 points higher.

It is logical objection that the Level of risk is a subjective variable and a comparable situation can be considered little risky by one respondent and very risky by the other. On the other hand, the discussion on subjective variables in the literature is wide and they are still being used. It has already been argued that people are influenced by the subjectively perceived risk, and not by the objective one.

For other variables, we have again the expected impact. The amount of risk accepted is enhanced by education, career preferences and not family preferences, pride of respondents, previous request for an increase in salary, income, individual approach, partnership and a higher risk are accepted by rather younger respondents. An interesting finding is that the amount of risk accepted is not affected by children nor their number, there is no difference between respondents in middle age or older and we have not demonstrated either difference across regions and within differently sized cities.

Differences between men and women on the labour market in the Czech Republic demonstrably exist. It is shown that after cleaning from other effects, these differences are smaller, but still significant. Outside the theories of social and cultural determination, there are several economic explanations, such as a different relationship to the competition (which can also be determined socially or culturally) or evaluation of their own abilities (which is subject to the same).

Gneezy, Niederle and Rustichini (2003) found in laboratory experiments that the performance of men is influenced more by competition circumstances than the performance of women. In a situation of competition, the men were able to make additional efforts, while women were not. Also Croson and Gneezy (2009) in the laboratory confirmed that men are more 
susceptible to competition, understand it as a challenge, an opportunity to apply the skills. Women, on the contrary, showed much less preference for a competitive environment. Men and women can freely choose different working environment (self-selection) just in terms of the level of risk. The explanation for their assertion is sought in genetics and upbringing.

Correll (2004) also examined by experiment, how the evaluation of their own skills and competencies affects the careers of men and women. The model implies that when men and women have different evaluations of their own skills and competencies in fulfilment of relevant tasks, they will shape different aspirations for the development of their careers. This was confirmed by the data from the experiment. Men rated their skills higher than women, and also had higher aspirations for career and competences to fulfil the task than women, even though their skills were the same. Men and women then did different career choices. The author sees the explanation in different preferences and different ways to maximize the utility for men and women, which subsequently leads to differences in men's and women's choices about careers. (Correll, 2004). Thus the hypothesis that gender differences in selfvaluation of skills and competencies lead to gender difference in shaping aspirations for a career course, to different preferences and different career choices, proved to be confirmed in this research.

Thus it is proved that men evaluate their skills and competencies higher than women, and this affects their career choices. This is an interesting hypothesis and it would be appropriate to test it also on the Czech data, which are unfortunately not available for us.

\section{Conclusion}

The question of differences between men and women in the labour market is constantly and widely discussed topic, not only in economics. This paper focuses on the theory of preferences and shows that this theory is valid also on the Czech labour market. It confirmed that part of the wage gap between men and women can be explained by discrimination, but also part of the employees' own preferences. If women have lower wages because they prefer them in order to have any other non-monetary rewards, such as better working relationships and lower stress, then it may be part of the wage difference accorded to preferences.

In this paper, we posed three hypotheses, which we verified on the basis of four models using 1984 observations of Czech employees in 2011.

The first hypothesis directly examined the preferences of intrinsic rewards for the level of salary. On the base of the answers about the preferences of the respondents, a summary variable was prepared, which identified respondents with a preference intrinsic rewards. The first hypothesis then said that women will prefer intrinsic rewards compared to the 
salary more likely than men. This hypothesis was verified at several levels. On a simple comparison of the actual variable, it was showed that women prefer salary actually less, even in all five categories of the variable. Moreover, this fact is true even after cleaning the impact from other significant variables.

The second hypothesis was based on the finding that in case of people with university education, this difference was not observed. Additionally, previous research has found that university education itself increases the preference for a higher salary. So the hypothesis was that women with a university will prefer the intrinsic rewards as well as men with university. At the same time, we assumed that university brings in the Czech Republic increased preference salary against intrinsic rewards. For these purposes, additional model was compiled, which showed that the hypothesis is valid only in its first half. It turned out that among university-educated respondents, the gender is not important. On the other hand, we found in the Czech Republic the opposite relationship than, for example Barbulescu and Bidwell (2013). Czech data shows that university is associated with a higher preference intrinsic rewards, by $40 \%$. Since these are subjectively reported data, it is possible that university educated people with higher salary state about themselves, that they do not prefer higher salary because they already have it. The influence of income on the preference of income, however, proved to be positive. The explanation may be in really different preferences Czech of university graduated employees.

The third hypothesis states that women prefer less risk. For this, we compiled two more models in a similar specification as for the first two hypotheses. It turned out that women actually prefer less risk than men, by 0.7 points on a scale of $0-10$.. University adds to women a bonus to the risk preference 0.5 point and to men 0.4 . University educated women prefer more risk, but still less than men, although the gap narrowed by 0.1 percentage points. The third hypothesis was thus confirmed.

Based on the available data it is therefore clear that in the Czech Republic, women prefer intrinsic rewards against the salary more likely than men, while for people with university education, gender does not matter. Women are also impacted by lower risk preferences than men, both among university educated and with lower levels of education.

\section{References:}

1. ATKINSON, S.M.; BAIRD, S.B. and FRYE, M.B. (2003). Do Female Mutual Fund Managers Manage Differently? Journal of Financial Research, Vol. 26, No. 1, pp. 1- 18.

2. BARBULESCU, R. and BIDWELL, M. (2013). Do Women choose different Jobs from Men? Mechanism of Application Segregation in 
the Market for Managerial Workers. Organization Science, Vol. 24, No. 3, pp. $737-756$.

3. BECKER, G.S. (1964). Human Capital: A theoretical and empirical analysis, with special reference to education. Chicago, University of Chicago Press. ISBN 978-0-226-04120-9.

4. BECKER, G.S. (1985). Human capital, effort, and the sexual division of labor. Journal of Labor Economics, Vol. 3, pp. S33- S58.

5. BECKER, G.S. (1997). Teorie preferencí. Praha, Grada Publishing. ISBN 80-7169-463-0.

6. BETZ, M., and O'CONNELL, L. (1989). Work Orientations of Males and Females: Exploring the Gender Socialization Approach. Sociological Inquiry, Vol.59, pp. $318-330$.

7. BIELBY, D. D. and BIELBY, W.T. (1988). She Works Hard for the Money: Household Responsibilities and the Allocation of Work Effort. The American Journal of Sociology, Vol. 93, No. 5, pp. 1031-1059.

8. BLAU, F.D. and KAHN, L.M. ( 2000). Gender Differences in Pay. Journal of Economic Perspective, Vol. 14, No. 4, pp. 75-99.

9. BLAU, F.D. and KAHN, L.M. (2007). The Gender Pay Gap: Have Women Gone as far as They Can? Academy of Management Perspectives. Vol. 21, Issue 1, pp. 7-23.

10. BROŽOVÁ, D. and STROUKAL, D. (2015). Teorie preferencí a kariéra žen na českém trhu práce. Politická ekonomie, Vol. 63, No. 3, pp. 382-399.

11. CORRELL, S.J. (2004). Constraints into Preferences: Gender, Status, and Emerging Career Aspirations. American Sociological Review, Vol. 69, No.1 (Feb. 2004), pp. 93-113.

12. CROSON, R. and GNEEZY, U.(2009). Gender Differences in Preferences, Journal of Economic Literature, Vol. 47, No. 2 (Jun., 2009), pp. 448-474.

13. DAYMONT, T.N. and ANDRISANI, P.J. (1984). Job Preferences, College Major, and the Gender Gap in Earnings. The Journal of Human Resources, Vol. 19, No. 3 (Summer 1984), pp. 408-428.

14. ENGLAND, P.S. and LI, S. (2006). Desegregation Stalled: The Changing Gender Composition of College Majors, 1971 - 2002. Gender and Society, Vol. 20, No. 5, pp. 657-677.

15. GNEEZY, U.; NIEDERLE, M. and RUSTICHINI, A. (2003). Performance in Competitive Environments: Gender Differences. Quarterly Journal of Economics, Vol.118, No. 3, pp. 1049 -74.

16. HAKIM, C. (2000). Work-lifestyle Choices in the 21st Century. Oxford University Press, ISBN 978-0-19-924210-8. 
17. HUFFMAN, M.L. et. al. (2010). Engendering Change; Organizational Dynamics and Workplace Gender Desegregation, 1975 - 2005. Administrative Science Quarterly, Vol. 55, No. 2, pp. 255 - 277.

18. HULL, K.E. and NELSON, R.L. (2000). Assimilation, Choice, or Constraint? Testing Theories of Gender Differences in the Careers of Lawyers. Social Forces, Vol. 79, No. 1, pp. 229 - 264.

19. JOHNSON, J., E. and POWELL, P.L. (1994). Decision Making, Risk and Gender: Are Managers Different? British Journal of Management, Vol. 5, No. 2, pp.123-38.

20. KONRAD, A.M.; CORRIGALL, E.; LIEB, P. and RITCHIE, J. (2000a). Sex Differences and Similarities in Job Attribute Preferences: A Meta-analysis. Psychological Bulletin, Vol.126, No. 4, pp. 593-641.

21. KONRAD, A.M.; CORRIGALL, E.; LIEB, P. and RITCHIE, J. (2000b). Sex Differences in Job Attribute Preferences among Managers and Business Students. Group and Organization Management, Vol. 25, No. 2, June 2000, pp. 108 - 131.

22. KONRAD, A.M.; YANG, Y.; GOLDBERG, C. and SULLIVAN, S.E.(2005). Preferences for Job Attributes Associated with Work and Family: A Longitudinal Study of Career Outcomes. Sex Roles, Vol. 53, No. 5/6, September 2005, pp. $303-315$.

23. MARINI, M.M. et al. (1996). Gender and Job Values. Sociology of Education, Vol. 69, No. 1, pp. 49 - 65.

24. MENEGHAN, E.G. (1991). Work Experiences and Family Interaction Processes: The long reach of the job? Annual Review of Sociology, Vol. 7, pp. $419-444$.

25. MILES, P.C. (2013). Why Do Educated, Successful Women Leave the Workforce? American International Journal of Social Science, Vol.2, No. 2, March 2013.

26. MOEN, P.N. (1992), Women's Two Roles: A Contemporary Dilemma. New York: Auburn House. ISBN 9780865691988.

27. O'CONNELL, L. and BETZ, M. (1996). Gender Differences in Work Interests. In Dubeck, P.and Borman, K., (eds.), Women and Work: A Handbook, pp. 284 - 287. New York: Garland. ISBN 9780824076474

28. O'NEILL, O.A. and O'REILLY, C.A. ( 2010). Careers as tournaments: the impact of sex and gendered organizational culture preferences on MBA's income attainment. Journal of Organizational Behavior, Vol. 31, No. 6, pp. $856-876$.

29. POLACHEK, S.W. (1978). Sex Differences in College Major. Industrial and Labor Relations Review, Vol.31, July 1978, pp. 498 508.

30. TOLBERT, P.S. and MOEN, P. (1998). Men's and Women's Definition of „Good“ Jobs: Similarities and Differences by Age and 


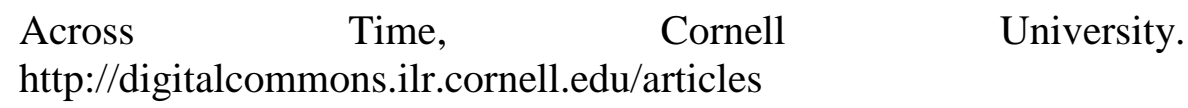

